\title{
PENGARUH PEMBERIAN CONSTRUCTIVE FEEDBACK DALAM ASESMEN PORTOFOLIO TERHADAP KEMAMPUAN KOGNITIF SISWA SMAN 3 PADANG
}

\author{
Rahmi Zulva ${ }^{1}$, Gusnedi ${ }^{2}$ \\ ${ }^{1}$ Pendidikan Fisika STKIP PGRI Sumatera Barat \\ ${ }^{2}$ Pendidikan Fisika Universitas Negeri Padang \\ E-mail : rahmi.zulva@gmail.com \\ http://dx.doi.org/10.22202/jrfes.2015.v2i1.1664
}

\begin{abstract}
In the process of learning physics in SMAN 3 Padang, less teachers motivate students to learn, so that learning physics is less effective. Students still considers physics is difficult and creepy, so that the students' physics cognitive ability is below the minimum completeness criteria (KKM). The purpose of this study was to determine the effect of giving constructive feedback on portfolio assessment on cognitive abilities physics class X SMAN 3 Padang. This research is a Quasi Experimental. Sampling was done by cluster random sampling. Data was collected using a physics cognitive ability objective matter as much as 30 items. Data were analyzed using two similarity test average (t-test) on the real level of 0.05 . Results obtained student experiment class and control class 60.7866 .57 . Furthermore, the analysis of the $t$ test obtained $t(74)=3.475$ is greater than t table $(0.95)(74)=1.6676$ on the real level of 0.05 , thus working hypothesis is accepted. So giving Constructive Feedback In Portfolio Assessment influencing the physics students' cognitive abilities
\end{abstract}

Key Word: cognitive abilities, constructive feedback, portofolio asesment

\begin{abstract}
Abstrak
Dalam proses pembelajaran fisika di SMAN 3 Padang, guru kurang memotivasi siswa dalam belajar, sehingga pembelajaran fisika kurang efektif. Siswa masih menganggap fisika itu sulit dan menyeramkan, sehingga kemampuan kognitif fisika siswa masih dibawah kriteria ketuntasan minimum (KKM). Tujuan penelitian ini adalah untuk mengetahui pengaruh pemberian constructive feedback dalam asesmen portofolio terhadap kemampuan kognitif fisika siswa kelas X SMAN 3 Padang. Jenis penelitian ini adalah Quasi Experimental. Pengambilan sampel dilakukan secara Cluster Random Sampling. Data kemampuan kognitif fisika dikumpul menggunakan soal objektif sebanyak 30 butir. Teknik analisis data menggunakan uji kesamaan dua rata-rata (uji t) pada taraf nyata 0,05. Hasil yang diperoleh siswa kelas eksperimen 66,57 dan kelas kontrol 60,78. Selanjutnya dengan analisis uji $t$ diperoleh $t_{\text {hitung(74) }}=3,475$ lebih besar dari $t_{\text {tabel(0,95)(74) }}=1,6676$ pada taraf nyata 0,05, dengan demikian hipotesis kerja diterima. Jadi pemberian Constructive Feedback Dalam Asesmen Portofolio memberi pengaruh terhadap kemampuan kognitif fisika siswa.
\end{abstract}

Kata Kunci : asesmen portofolio, constructive feedback, kemampuan kognitif. 
I. PENDAHULUAN

Pemerintahan telah berupaya untuk meningkatan kualitas mutu pendidikan, diantaranya dengan melakukan penyempurnaan kurikulum. Salah satu mendasar perubahan kurikulum KBK menjadi KTSP yaitu pada asesmen berbasis kelas. Asesmen berbasis kelas merupakan proses pengumpulan dan penggunaan informasi oleh guru untuk pemberian keputusan terhadap hasil belajar siswa berdasarkan tahapan kemajuan belajar siswa didapatkan potret kemampuan siswa sesuai dengan kompetensi yang ditetapkan dalam kurikulum. Asesmen tersebut dilakukan secara komprehensif sepanjang proses pembelajaran dikelas berlangsung (Muchlis, M. 2007:78).

Salah satu asesmen yang digunakan dalam asesmen berbasis kelas yaitu asesmen portofolio. Asesmen portofolio merupakan asesmen autentik yang dapat dilakukan melalui kumpulan dan review hasil belajar (Grace \& Cathy 1992). Portofolio proses belajar siswa ini menurut Gitomer \& Dutch (1994:321-323) adalah menyangkut aspek belajar kognitif, afektif dan psikomotor.

Disamping itu, asesmen portofolio merupakan suatu proses yang kontiniu dan berkesinambungan. Setiap akhir pembelajaran, guru dapat menilai hasil dan kemajuan siswa.

Peningkatan kemampuan siswa dari waktu ke waktu dapat lebih dioptimalkan dengan menggunakan umpan balik (feedback). Feedback ini memiliki beberapa fungsi dan tingkatan diantaranya sebagai pembangun (constructive). Tujuan dari constructive feedback ini untuk memberikan informasi yang akan memberikan perbaikan atau kemajuan terhadap siswa. Constructive feedback yang diberikan kepada siswa dalam bentuk tulisan-tulisan atau komentar yang sifatnya membangun.

Dalam pengamatan, peneliti melihat ada beberapa cara yang dilakukan guru untuk menarik minat siswa dalam pembelajaran fisika, misalnya dengan menggunakan media powerpoint, diskusi kelompok dan pemberian bonus. Tetapi kemampuan kognitif fisika siswa masih dibawah kriteria ketuntasan minimum (KKM).

Adapun pada kegiatan laboratorium, terlihat siswa hanya bermain-main saja, sehingga ketika dilihat laporan kegiatan laboratorium siswa dibuat asalasalan saja dan siswa tidak mengetahui kebenaran laporan tersebut. Guru hanya menilai betul atau salahnya suatu tugas, sehingga siswa tidak mengetahui mengapa dia salah dalam membuat tugas dan bagaimana jawaban yang benarnya. Untuk itu penulis mencoba melakukan penelitian dengan memberikan feedback kepada tugas-tugas siswa tersebut berupa kalimat-kalimat positif dan membangun.

\section{TINJAUAN PUSTAKA}

\section{Pembelajaran KTSP}

Pembelajaran berbasis KTSP yaitu pembelajaran yang melandaskan materi ajar, proses pelaksanaan dan cara penilaian hasil belajar pada KTSP. Mulyasa (2007:1) dinyatakan:"KTSP merupakan operasional yang disusun, dikembangkan, dan dilaksanakan oleh setiap satuan pendidikan yang sudah 
siap dan mampu mengembangkannya dengan memperhatikan dan berdasarkan standar kompetensi serta kompetensi dasar yang dikembangkan oleh Badan Standar Nasional Pendidikan (BSNP)".

KTSP bertujuan untuk meningkatkan mutu dan kualitas setiap komponen yang terlibat di dalam proses pendidikan itu sendiri. Komponen tersebut adalah sekolah, warga sekolah dan masyarakat pengembang kurikulum.

\section{Asesmen Portofolio}

Menurut Collins (1992) dalam Susilo (2003), portofolio merupakan suatu wadah yang berisi kumpulan bukti pekerjaan siswa dalam kurun waktu tertentu secara sistematis untuk mencapai tujuan tertentu, yang berisi rangkuman diskusi, jurnal belajar, hasil pengamatan, refleksi diri dan identitas portofolio, yang menunjukkan perkembangan siswa dari waktu ke waktu.

Portofolio penilaian (assesment) diartikan sebagai kumpulan fakta atau bukti dan dokumen yang berupa tugas-tugas yang terorganisir secara sistematis dari seseorang secara individual dalam proses pembelajaran. Selain itu juga diartikan sebagai koleksi sistematis dari siswa dan guru untuk menguji proses dan prestasi belajar.

Portofolio ada tiga jenis, yaitu: portofolio perkembangan, portofolio pamer dan portofolio komprehensif. Pada penelitian ini digunakan jenis portofolio perkembangan. Portofolio yang digunakan berupa kumpulan resume materi yang akan dipraktikumkan, kumpulan laporan praktikum siswa dan kumpulan tugas siswa.

\section{Constructive Feddback}

Constructive feedback adalah memberikan hal-hal yang perlu terhadap perkembangan seseorang atau banyak orang yang menganggap constructive feedback menyampaikan hal yang sesungguhnya yang bermanfaat. Tujuan dari constructive feedback ini yaitu untuk memberi informasi yang akan memberikan perbaikan atau kemajuan terhadap peserta didik dan akan membuat hasil yang bagus.

Apabila constructive feedback bertujuan untuk membangun dan memberikan informasi yang akan memberikan perbaikan, sebaiknya diberikan umpan balik yang positif.

\section{Kemampuan Kognitif}

Kemampuan kognitif meliputi kemampuan yang menyatakan kembali konsep atau prinsip yang telah dipelajari dan kemampuan intelektual. Menurut Bloom dalam Sudjana (2001:22) kemampuan kognitif meliputi:
a. Mengenal
b. Memahami
c. Penerapan
d. Analisis
e. Sintesis
f. Evaluasi

\section{METODOLOGI PENELITIAN}

Sesuai dengan masalah yang diteliti, maka jenis penelitian ini adalah quasi eksperimen. Penelitian ini menggunakan dua kelas sampel, yaitu kelas eksperimen dan kelas kontrol. Perlakuan pada kelas eksperimen yaitu penilaian dengan constructive feedback, sedangkan kelas kontrol penilaian tidak dengan constructive feedback.

Tabel 1. Rancangan Penelitian

\begin{tabular}{|c|c|c|}
\hline Kelas & Perlakuan & $\begin{array}{c}\text { Tes } \\
\text { terakhir }\end{array}$ \\
\hline Eksperimen & $\mathrm{X}$ & $\mathrm{T}$ \\
\hline Kontrol & - & $\mathrm{T}$ \\
\hline
\end{tabular}

Sumber: (Sumadi,2006:104)

Keterangan:

$\mathrm{X}$ : perlakuan yang diberikan pada kelas eksperimen 
$\mathrm{T}$ : Tes akhir yang diberikan pada

kelas eksperimen dan kelas kontrol

Populasi dalam penelitian ini yaitu seluruh siswa SMAN 3 Padang yang terdaftar pada semester II tahun ajaran 2009/2010.

Tabel 2. Jumlah siswa kelas X SMAN

3 Padang Semester II tahun ajaran 2009/2010.

\begin{tabular}{|c|c|c|c|}
\hline No & Kelas & Jumlah siswa & $\begin{array}{l}\text { Nilai } \\
\text { kelas }\end{array}$ \\
\hline 1 & $\mathrm{X}_{3}$ & 39 orang & 42,38 \\
\hline 2 & $\mathrm{X}_{4}$ & 38 orang & 42,26 \\
\hline 3 & $\mathrm{X}_{5}$ & 38 orang & 42,44 \\
\hline 4 & $\mathrm{X}_{6}$ & 40 orang & 42,31 \\
\hline 5 & $\mathrm{X}_{7}$ & 39 orang & 43,46 \\
\hline 6 & $\mathrm{X}_{8}$ & 40 orang & 46,35 \\
\hline 7 & $\mathrm{X}_{9}$ & 39 orang & 45,32 \\
\hline
\end{tabular}

Sedangkan sampel diambil dengan cluster random sampling. Teknik ini menghendaki kelompok-kelompok dalam pengambilan sampel berdasarkan kelompok-kelompok yang ada pada populasi.

Variabel dalam penelitian ini terdiri dari variabel bebas, variabel kontrol dan variabel terikat. Variabel bebas yaitu pemberian constructive feedback. variabel bebas yaitu kemampuan kognitif. Variabel kontrol yaitu guru, bahan ajar, materi pelajaran dan jumlah jam pelajaran adalah sama.

Instrumen pada penelitian ini menggunakan tes tertulis berupa tes pilihan ganda yang diberikan pada akhir penelitian. Sebelum instrumen diberikan kepada siswa, instrumen tersebut diuji coba terlebih dahulu kepada siswa yang telah mempelajari mata pelajaran tersebut, setelah diuji coba, maka dianalisis seperti yang diungkapkan oleh Arikunto (2006:207) "analisis soal antara lain bertujuan untuk mengadakan identifikasi soal-soal yang baik, kurang baik dan jelek. Dengan analisis soal dapat diperoleh kejelekan sebuah soal dan petunjuk untuk mengadakan perbaikan". Analisis soal yang telah diuji coba meliputi analisis validitas, reliabilitas, daya beda dan tingkat kesukaran soal.

Setelah soal diuji coba dan dianalisi, kemudian soal dapat disebarkan kepada sampel penelitian. Setelah diperoleh data, kemudian data tersebut dianalisis. Analisis data yang dilakukan untuk menguji apakah hipotesis diterima atau ditolak.

\section{HASIL DAN ANALISA}

Berdasarkan analisis data yang telah dilakukan, kemampuan kognitif siswa menunjukkan bahwa setelah diberikan perlakuan / treatment yang berbeda, nilai rata-rata kelas eksperimen lebih baik daripada nilai rata-rata kelas kontrol. Nilai rata-rata pada kelas eksperimen 66,57, sedangkan nilai ratarata pada kelas kontrol 60,78. Hal ini disebabkan oleh perlakuan yang berbeda, dimana pada kelas eksperimen diberi constructive feedback pada tugas-tugas aplikasi konsep, resume materi yang akan dipraktikumkan dan laporan praktikum. Jika ditinjau dari Kriteria Ketuntasan Minimal (KKM) yang ditentukan sekolah yaitu 65, nilai rata-rata kemampuan kognitif fisika siswa pada kelas eksperimen mengalami peningkatan dibandingkan kelas kontrol. Sebelum dilaksanakan treatment kelas eksperimen yang lulus KKM sangat sedikit sekali dan setelah dilaksanakan treatment siswa yang lulus KKM meningkat. Tingginya peningkatan nilai siswa yang lulus KKM pada kelas eksperimen dibandingkan dengan kelas kontrol diyakini karena perbedaan perlakuan yang diberikan pada kedua kelas.

Pada penelitian ini, peneliti menggunakan bahan tertulis berupa LKS yang dirancang sendiri oleh peneliti dan laporan hasil praktikum siswa yang dibuat 
oleh siswa. Siswa diminta untuk mengerjakan LKS dalam kelompok praktikumnya masing-masing. Setelah selesai praktikum, siswa diminta untuk mengumpulkan data awal hasil percobaannya dan seminggu kemudian mengumpulkan laporan (hasil akhir) praktikum.

Pada laporan kegiatan laboratorium tersebut penulis memberikan constructive feedback secara tertulis berupa kalimatkalimat positif. Setelah diberi constructive feedback pada laporan kegiatan laboratorium siswa tersebut, guru mengembalikan secepatnya laporan tersebut, sehingga siswa tahu kesalahannya dalam membuat laporan kegiatan laboratorium.

$$
\text { Selain laporan kegiatan }
$$

laboratorium, peneliti juga memberikan constructive feedback pada tugas siswa berupa resume dengan topik yang akan dilakukan dilaboratorium dan tugas aplikasi konsep fisika. Constructive feedback yang diberikan juga berupa kalimat-kalimat positif. Pada awalnya siswa membuat laporan hanya asal-asalan saja, misalnya pada cover laporan tersebut. Kebanyakan siswa tidak membuat cover pada laporannya. Setelah diberi constructive feedback pada laporan siswa tersebut, laporan siswa untuk kegiatan laboratorium selanjutnya lebih menarik.

Hal ini juga terlihat pada isi laporan kegiatan praktikum siswa. Pada umumnya siswa susah membuat rumusan masalah dan rumusan hipotesisnya. Siswa tidak mengetahui bagaimana cara membuat rumusan masalah dan rumusan hipotesis dengan benar. Selain itu siswa juga asal-asalan membuat kesimpulan dari kegiatan loboratorium tersebut. Banyak siswa yang membuat kesimpulan dari percobaan yang telah dilakukan tidak sesuai dengan tujuan.

Pada kumpulan resume dan tugastugas aplokasi konsep, peneliti memperhatikan kebenaran dan kejelasan tugas. Pada awalnya siswa tersebut membuat resume dengan asal-asalan saja, misalnya resume siswa tersebut tidak lengkap atau resume siswa tersebut tidak sesuai dengan apa yang akan dikerjakan pada saat kegiatan laboratorium.

Laporan kegiatan siswa yang pada awalnya dibuat dengan asal-asalan, setelah diberi constructive feedback laporan siswa tersebut, untuk membuat laporan selanjutnya lebih terlihat menarik dan isi laporannya sesuai dengan apa yang diharapkan. Siswa dapat membuat rumusan masalah dan rumusan hipotesis dengan benar. Siswa juga dapat membuat kesimpulan kegiatan laboratorium sesuai dengan tujuan kegiatan laboratorium.

Begitu juga dengan tugas resume dan tugas aplikasi konsep. Setelah diberi constructive feedback pada tugas resume tersebut, untuk mebuat tugas resume dan tugas aplikasi konsep selanjutnya, siswa membuat tugas-tugas tersebut dengan lengkap.

Laporan kegiatan laboratorium siswa, tugas resume dan tugas aplikasi konsep siswa tersebut dijadikan sebagai bahan portofolio dalam penelitian ini. Dimana pada penelitian ini peneliti menggunakan portofolio yang bertujuan untuk melihat perkembangan siswa. Terlihat bahwa pada kelas eksperimen perkembangan laporannya dan resumenya semakin baik dibandingkan dengan kelas kontrol. Hal ini diyakini karena perbedaan pemberian constructive feedback yang hanya diberikan pada kelas eksperimen.

Pemberian constructive feedback ini ada hubungannya dengan hasil belajar siswa. Setelah diberi constructive feedback pada kelas eksperimen, motivasi belajar siswa meningkat dan penguasaan materinya semakin mantap. Sehingga hasil belajar pada kelas eksperimen lebih baik dan lulus KKM dibandingkan dengan kelas kontrol.

\section{KESIMPULAN}

Setelah dilakukan analisa tes hasil belajar fisika dalam penelitian ini diperoleh kesimpulan bahwa kemampuan 
kognitif siswa dalam mata pelajaran fisika dengan pemberian constructive feedback ini lebih baik dibandingkan kemampuan kognitif siswa tanpa diberi constructive feedback. Hal ini dapat dilihat dari nilai rata-rata kemampuan kognitif antara kelas eksperimen lebih baik dari kelas kontrol secara signifikan pada taraf nyata 0,05 . Dengan demikian dapat disimpulkan bahwa terdapat pengaruh kemampuan kognitif siswa yang berarti pada pemberian constructive feedback dalam asesmen portofolio.

\section{DAFTAR PUSTAKA}

Arikunto, S. (2006). Dasar-Dasar Evaluasi Pendidikan . Jakarta : Bumi Aksara.

BNSP. (2006). Panduan Penyusunan KTSP Jenjang Pendidikan Dasar dan Menengah. Jakarta : Depdiknas.
Muslich, M. (2007). KTSP Pembelajaran Berbasis Kompetensi dan Kontekstual. Jakarta : Bumi Aksara.

Mulyasa. 2007. Kurikulum Tingkat Satuan Pendidikan. Bandung : Rosda Karya

Slameto. (1999). Evaluasi Pendidikan . Jakarta : Bumi Aksara.

Slameto. (2000). Belajar dan

Faktor-Faktor yang Mempengaruhi. Jakarta : Rineka Cipta.

Sudijono, A. (2006). Pengantar Statistik Pendidikan. Jakarta : Grafindo Persada.

Sudjana. (1996). Metode Statistik. Bandung Transito. 